\title{
Natural Sciences and Anthropology in Didymus the Blind's Commentaries on the Bible: a Possible Aristotelian Influence
}

\author{
Marco Zambon
}

This paper gathers from Didymus' exegetical works (in particular from the lessons on the book of Psalms and on the Ecclesiastes) all significant testimonies concerning his knowledge of natural sciences and his anthropological doctrine. Based on these materials I will briefly discuss their possible sources, trying to answer following questions: a) What kind of Aristotelian doctrines can we recognise in Didymus' statements concerning cosmology, biology and anthropology? b) Is there sufficient evidence to conclude that he had, beside the Organon, also a direct knowledge of other Aristotelian works? c) How important are methods and doctrines coming from Aristotle for Didymus' exegetical practice?

\section{Christianism and Greek Paideia}

Didymus was almost only a name until the half of the XXth century ${ }^{1}$, when in a stone quarry not far from Cairo in Egypt a large quantity of papyrus sheets was found which originally formed eight codices. ${ }^{2}$ Six of them contained exegetical works which could be attributed to Didymus: commentaries on the books of Genesis, Job and

\footnotetext{
${ }^{1}$ Origen, Evagrius, and Didymus were condemned as heretics in 553; on the circumstances of the condemnation: Franz R. Diekamp, Die origenistischen Streitigkeiten im 6. Jahrhundert und das fünfte allgemeine Concil (Münster: Aschendorff, 1899), 129-138; Antoine Guillaumont, Les "Kephalaia gnostica" d'Èvagre le Pontique et l'histoire de l'Origénisme chez les Grecs et les Syriens (Paris: Seuil, 1962), 81-136. Following his condemnation, much of Didymus' work was lost. Until the middle of the 18th century, only the treatise De Spiritu sancto, a part of the Contra Manichaeos and a number of exegetical fragments contained in the chains were known; these are the materials included in Jacques-Paul Migne's edition (Patrologiae cursus completus. Series Graeca 39: 269-1818).

${ }^{2}$ On the findings of Tura: Louis Doutreleau, "Que savons-nous aujourd'hui des papyrus de Toura?", Recherches de science religieuse 43 (1955): 161-176; Ludwig Koenen - Louis Doutreleau, "Nouvel inventaire des Papyrus de Toura", Recherches de science religieuse 55 (1967): 547-564; Ludwig Koenen - Wolfgang Müller-Wiener, "Zu den Papyri aus dem Arsenioskloster bei Tura", Zeitschrift für Papyrologie und Epigraphik 2 (1968): 41-63.
} 
Zechariah and the transcript of classes on part of the book of Psalms and on the book of Ecclesiastes. Thanks to this discovery Didymus is now one of the best known Christian teachers of late antiquity. ${ }^{3}$ Though was blind since his childhood, he was nevertheless he was celebrated by his contemporaries for his learning. Rufinus, who was his disciple, describes him as an accomplished scholar and a philosopher:

[...] The Lord lighted him like a lamp shining with a divine light. [...] In a short time, trained by God, he acquired such a great scientific knowledge of divine and human things that he became teacher at the church school and was highly approved by Athanasius and by other wise men of the church of God. ${ }^{4}$

This judgement is confirmed by the sources we have: Didymus was familiar with philosophical and scientific doctrines, and he used them both to explain the Holy Scripture and to argue his own theological teachings against pagans and heretics. ${ }^{5}$ In doing this he followed the Origenian principle that the "treasures of the heathen" must be put in the service of the truth. ${ }^{6}$ What is interesting for us here is that the works of Didymus show a remarkable knowledge of Aristotle, which was not common among Christian authors.

${ }^{3}$ Overall presentations of Didymus: M. Zambon, "Didyme l'Aveugle", in Dictionnaire des philosophes antiques, ed. R. Goulet, (Paris: CNRS Éditions, 2018), 7: 485-513; Grant D. Bayliss, The Vision of Didymus the Blind. A Fourth-Century Virtue-Origenism (Oxford: Oxford University Press, 2015); Jonathan D. Hicks, Trinity, Economy, and Scripture: Recovering Didymus the Blind (Winona Lake: Eisenbrauns, 2015); Richard A. Layton, Didymus the Blind and his Circle in Late Antique Alexandria. Virtue and Narrative in Biblical Scholarship (Urbana - Chicago: University of Illinois Press, 2004); L. Doutreleau, "Vie et survie de Didyme 1'Aveugle du IVe siècle à nos jours", in Les mardis de Dar-el-Salam 1956-1957 (Paris: Vrin, 1959), 33-92.

${ }^{4}$ Rufin. HE II 7 (Die Griechischen Christlichen Schriftsteller der ersten drei Jahrhunderte 9/2: 1012): [...] velut lampadam quandam divina luce fulgentem Didymum dominus accendit. [...] brevi deo docente in tantam divinarum humanarumque rerum eruditionem ac scientiam venit, ut scholae ecclesiasticae doctor existeret, Athanasio episcopo ceterisque sapientibus in ecclesia dei viris admodum probatus [...].

${ }^{5}$ M. Zambon, "Didymos der Blinde", in Grundriß der Geschichte der Philosophie. Begründet von Friedrich Ueberweg - Völlig neu bearbeitete Ausgabe. Die Philosophie der Antike. Band 5/2: Philosophie der Kaiserzeit und der Spätantike, ed. Ch. Riedweg - Ch. Horn - D. Wyrwa (Basel: Schwabe Verlag, 2018), 1506-1518; Blossom Stefaniw, Mind, Text, and Commentary: Noetic Exegesis in Origen of Alexandria, Didymus the Blind and Evagrius Ponticus (Frankfurt am Main: Peter Lang, 2010).

${ }^{6}$ Orig. Ep. ad Greg. 1-2; Ex 11, 2; 12, 35; M. Pereira, "From the Spoils of Egypt: An Analysis of Origen's Letter to Gregory", in Origeniana Decima. Origen as Writer. Papers of the 10th International Origen Congress, ed. S. Kaczmarek - H. Pietras - A. Dziadowiec (Leuven - Paris Walpole MA: Uitgeverij Peeters, 2011), 221-248; P.F. Beatrice, "The Treasures of the Egyptians. A Chapter in the History of Patristic Exegesis and Late Antique Culture", in Studia Patristica, XXXIX, ed. M.J. Edwards - P. Parvis - F. Young (Leuven: Peeters, 2006), 159-183. 
Aristotle was an object of mistrust among Christian writers at least until the end of the IVth century, but it is not very clear how much Christian authors really knew about him. ${ }^{7}$ Was their critical attitude based on a direct knowledge of his thought and writings or did the Christian theologians rely on second hand and rather hostile sources? ${ }^{8}$ In a letter of Jerome $(E p .70,4)$ we read that Origen composed his own Stromata proving the truth of Christian religion through evidences from Plato, Aristotle, Numenius and Cornutus. This is a very generic statement, but it could be that Origen actually knew Aristotle and the Peripatetic tradition better than we can guess from our remaining evidence. ${ }^{9}$ On the other side, the summary of Aristotelian doctrine given by Eusebius of Caesarea in book $\mathrm{XV}$ of his Evangelical preparation shows that even a very learned Christian intellectual like him could, in reconstructing Aristotle's thought, completely ignore the authentic writings of Aristotle and rely only on indirect and hostile sources. ${ }^{10}$

To get an idea about how much Christian writers could know of the Aristotelian works, we should first consider which kind of Aristotelian corpus was available to them. ${ }^{11}$

${ }^{7}$ On the reception of Aristotle by Christian authors: Mark J. Edwards, Aristotle and Early Christian Thought (London - New York: Routledge, 2019); G. Karamanolis, "Early Christian Philosophers on Aristotle", in Brill's Companion to the Reception of Aristotle in Antiquity, ed. A. Falcon (Leiden - Boston: Brill, 2016), 460-479; M. Frede, "Les Catégories d'Aristote et les Pères de l'Église grecs", in Les Catégories et leur histoire, ed. O. Bruun - L. Corti (Paris: J. Vrin, 2005), 135-173; Johannes Zachhuber, "Das Universalienproblem in der griechischen Patristik und im frühen Mittelalter", Millennium 2 (2005): 137-174; ; L.J. Elders, "The Greek Christian Authors and Aristotle", in Aristotle in Late Antiquity, ed. L.P. Schrenk (Washington D.C.: The Catholic University of America Press, 1994), 111-142; David Runia, "Festugière Revisited: Aristotle in the Greek Patres", Vigiliae Christianae 43 (1989): 1-34; S. Lilla, "Aristotelismo", in Dizionario patristico di antichità cristiane, ed. A. Di Berardino (Casale Monferrato: Marietti, 1983), 1: 349363; A.J. Festugière, "Excursus C: Aristote dans la littérature grecque chrétienne jusqu'à Théodoret", in Id., L'idéal religieux des Grecs et l'Évangile (Paris: Gabalda, 1932), 221-263; Joseph de Ghellinck, "Quelques appréciations de la dialectique et d'Aristote durant les conflits trinitaires du IVe siècle", Revue d'histoire ecclésiastique 26 (1930): 5-42.

${ }^{8}$ Cf. Karamanolis, "Early Christian Philosophers on Aristotle", 463.

9 About Origen's knowledge of Aristotle: Karamanolis, "Early Christian Philosophers on Aristotle", 470-472; Ilaria Ramelli, "Alexander of Aphrodisias: A Source of Origen's Philosophy?", Philosophie Antique 13 (2013): 1-49; Henry Crouzel, Origène et la philosophie (Paris: Aubier, 1962) 31-35.

${ }^{10}$ Christian authors did not make any difference between Aristotle's doctrines and the later Peripatetic tradition: Karamanolis, "Early Christian Philosophers on Aristotle", 462.

${ }^{11}$ On the constitution and circulation of the Aristotelian corpus in the Hellenistic and Imperial Age: G. Feola, "Alcune considerazioni sull'ordinamento del corpus biologico di Aristotele", in La zoologia di Aristotele e la sua ricezione dall'età ellenestica e romana alle culture medievali. Atti della X settimana di Formazione del centro GrAL, Pisa, 18-20 novembre 2015, ed. M.M. Sassi - E. Coda - G. Feola (Pisa: Pisa University Press, 2017), 35-57; M. Hatzimichali, "Andronicus of Rhodes and the Construction of the Aristotelian Corpus", in Brill's Companion to the Reception of Aristotle in Antiquity, 81-100; J. Dillon, "The Reception of Aristotle in 
The Aristotelian corpus as we know it today established itself gradually during the first centuries of the C.E. As Porphyry (Vita Plot. 24, 2-11 H.-S.) shows, that at the beginning of the IV ${ }^{\text {th }}$ century the systematic ordering of the esoteric works, as we know it, was a fait accompli, which he attributed without any hesitation to Andronicus of Rhodes; but it is not said that the corpus thus constituted was widespread. It is possible that the apparently little knowledge Christian authors show of the esoteric Aristotelian works depended on the difficulty of getting them rather than on their lack of interest in them.

We must also take account of the doctrinal concerns of Christian writers. In general we can assume that they did not like to openly reveal their dependence on pagan culture; thus, Christian authors could actually have a wider knowledge of it than it appears from their writings. We have, in fact, some evidence that there was a tradition of Aristotelian studies among the Christians at Alexandria. Eusebius tells us that in the the Seventies of the III century a teacher called Anatolius, later bishop of Laodicea, was appointed as chief of the Aristotelian school of Alexandria:

Anatolius [...] was an Alexandrian by birth. Concerning his learning and education in Greek philosophy, namely, arithmetic and geometry, astronomy, and dialectics in general, as well as in the theory of physics, he was first among the ablest men of our time, and he was also at the head in the knowledge of rhetoric. It is reported that, for this reason, he was requested by the citizens of Alexandria to establish there the school of Aristotelian philosophy. ${ }^{12}$

Arius, Aetius and Eunomius are credited with the study of dialectics and of Aristotelian doctrine at Alexandria in the first half of the IVth century. ${ }^{13}$ Therefore we can conclude that Didymus had good opportunities to get acquainted with Aristotle's philosophy and works.

Aristotelian Doctrines in a Platonic Frame

Antiochus and Cicero", in Brill's Companion to the Reception of Aristotle in Antiquity, 183-201; Paul Moraux, Der Aristotelismus bei den Griechen Von Andronikos bis Alexander von Aphrodisias, I (Berlin - New York: Walter de Gruyter, 1973), 3-93; Id., Les listes anciennes des ouvrages d'Aristote (Leuven: Éditions universitaires de Louvain, 1951).

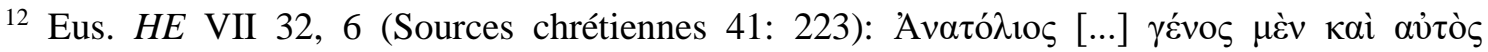

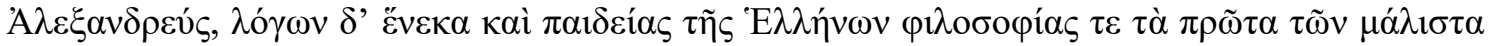

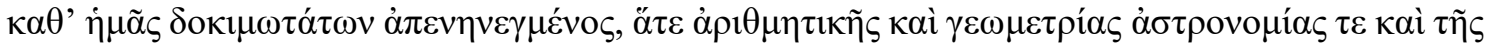

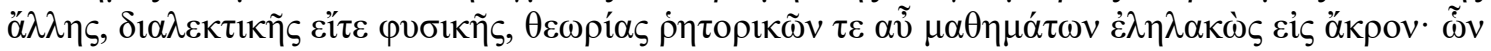

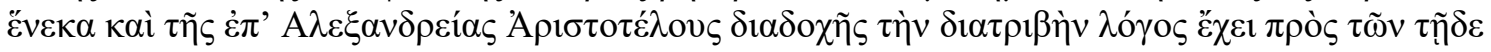

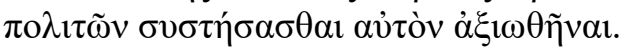

${ }^{13}$ Socr. HE I 5, 2; II 35, 4-5; Sozom. HE III 15, 7-8. 
Most of the philosophical doctrines we find in the writings of Didymus arise within a school tradition where Aristotelian and Stoic elements are mixed together into a Neoplatonic frame. An example is offered by the explanation of Eccl 7, 25 ("I and my

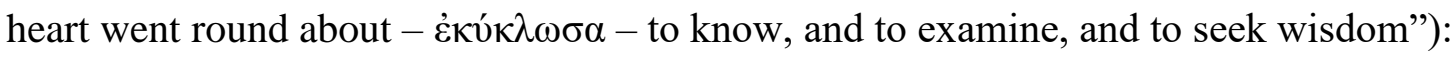

It has already been said many times that the heart means the intellect. Nevertheless the intellect does move neither obliquely nor straight; it turns around itself. Likewise as some of the pagans said that the noetic acts are like wheels and circles turning around. Of course, when the intellect tends towards external things and wants to receive a representation of sensible things, it doesn't turn around itself. But when it acts as intellect and it directs its attention towards itself, then it becomes the subject and the object of its noetic activity. Indeed the noetic activity always belongs to the intellect in actuality and, in that case, it is never dispersed towards the external things. ${ }^{14}$

Didymus speaks of "some of the pagans" but does not specify to which authors he refers. The doctrine that places the rational and directive part of the soul (the $\dot{\gamma} \gamma \varepsilon \mu o v i \kappa o ́ v)$ within the heart is of Stoic origin. ${ }^{15}$ The circular motion of the intellect around itself is a Platonic image used to describe either the motion of the universe (Tim. 34 A), or the motion of the soul (Tim. 37 A e C; Leg. X, 898 A-B). The remarks about the actuality of the intellect and the identity in it between the subject and the object of thinking are an Aristotelian heritage (Metaph. $\Lambda$ 7, 1072 b 19-21; 9, 1075 a 3-5). The synthesis of these elements does not come from Didymus: statements similar to those of him can be read in Proclus, but the doctrine expounded here by Didymus is also found in Plotinus and Porphyry. ${ }^{16}$

To establish the divinity of the Holy Spirit, Didymus distinguishes in De Spiritu sancto $(\S \S 17 ; 54-56)$ what is participable (capabilis) from what participates (capax I capiens): the participable (Holy Spirit) offers realities of a lower level (rational creatures) an ontological determination (sanctification) that makes them similar to itself, without

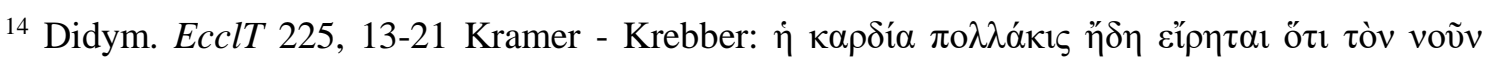

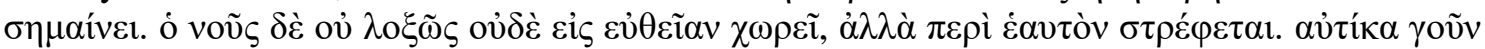

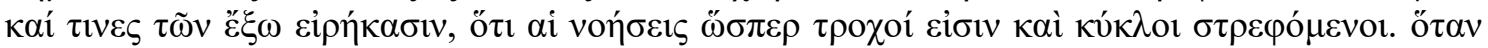

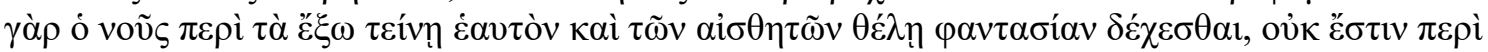

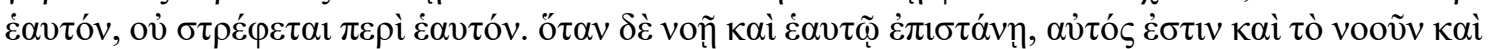

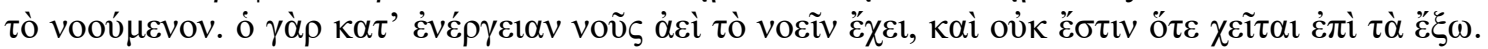
For the analysis of this passage: Marco Zambon, “" A servizio della verità": Didimo il Cieco 'lettore' di Aristotele", Studia Graeco-Arabica 2 (2012): 129-200, at 157-159.

${ }^{15}$ Didym. EcclT 33, 1; 44, 15-21; 98, 12-14; 165, 25; 315, 6-9; 337, 19-20; PsT 53, 18; 84, 25; 100, 28; 179, 14; 246, 16; 265, 20; 276, 26; 289, 16; 333, 16; SVF II 228; 235; 761; 809-811; 822; 837-839; 901-902.

${ }^{16}$ Procl., In Remp. II, p. 46, 18-27 Kroll; In Tim. II, p. 312, 22-26 Diehl; also Porph., Sent. 43, p. 55, 6-19; 44, p. 57, 1-6 Lamberz; Plot., Enn. V 3 [49], 5 H.-S.
} 
suffering in that process any diminution or alteration (cf. Plat. Tim. 42 E). ${ }^{17}$ This way of describing the causality of intelligibles and of establishing a hierarchy between participating and participated realities partly anticipates the doctrine set out in more systematic form by Proclus in propositions 23-24 and 26-27 of The Elements of Theology, but there are several precedents for it in Platonism of the imperial age. ${ }^{18}$ Although no direct connection can be established, Didymus must have had a not insignificant knowledge of contemporary Platonism and within this framework he also interpreted the Aristotelian doctrines he had integrated into his own thought.

There are general statements or definitions which derive from or agree with Aristotle's doctrine but which were very common in the philosophical language of his time, and do not imply that Didymus had a direct knowledge of Aristotle himself. They are interesting for us because, by using them without further explanations, the teacher supposed that his pupils too were familiar with them. In this way we can retrace the philosophical background shared by Didymus and his audience. An example of this kind of widespread doctrines is the explanation of the title which opens several psalms: "for

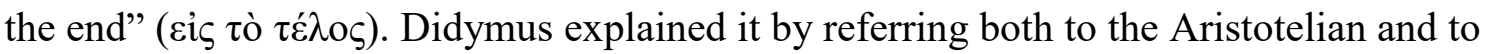
the Stoic definition of $\tau \varepsilon \dot{\lambda}$ os:

It has often been said about the end that it is "that thing for whose sake everything else happens, whereas it is not for the sake of any other thing"; it is also called "the ultimate object of desire" $[\ldots] \cdot{ }^{19}$

A deeper level of appropriation of Aristotle's thought is shown by passages containing explicit quotations from his works or the systematic use of typical Aristotelian doctrines, e.g. actuality as opposed to potentiality, the different kinds of change, the distinction

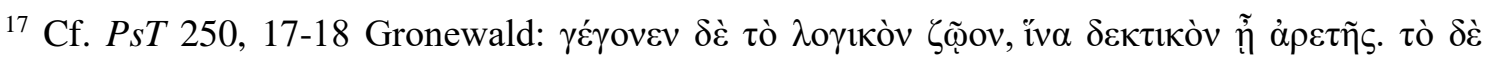

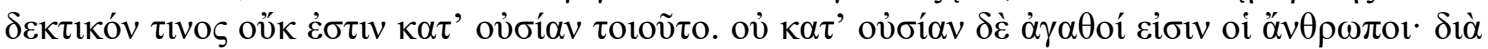

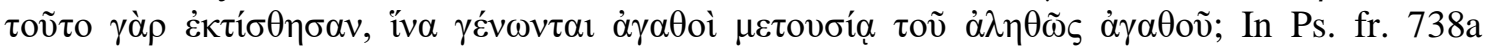

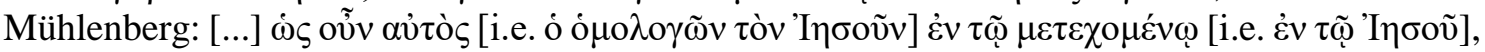

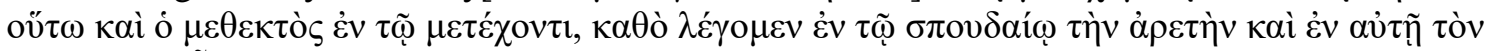

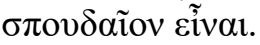

${ }^{18}$ K. Plaxco, "Didymus the Blind and the Metaphysics of Participation", in Studia Patristica, LXVII, ed. M. Vinzent (Leuven: Peeters, 2013), 227-237, at 235 refers to Porph. Symm. zet. ap. Nem. De nat. hom. 3, p. 42, 22-43, 8 Morani (= Porph. Fragm. 260 F Smith); Proclus, The Elements of Theology, ed. E.R. Dodds (Oxford: At the Clarendon Press, 1964), 210-218.

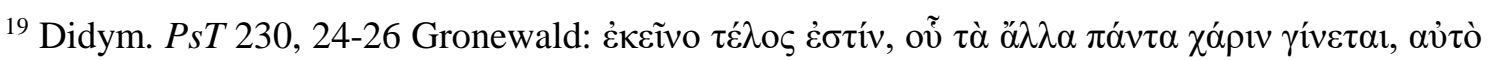

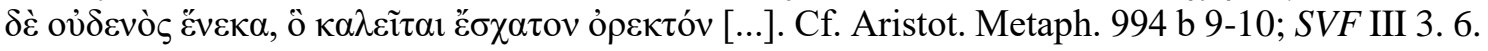
65. 183; Sext. Emp. Pyrr. hyp. I 25; Zambon, “A servizio della verità”, 196.
} 
between homonymous, synonymous and paronymous things. ${ }^{20}$ The analysis of these texts of Didymus shows that he was acquainted at least with a part of Aristotle's written works and with some fundamental teachings of him. ${ }^{21}$

An example of how Didymus creatively used Aristotelian notions in his theological reflection is offered by the way he distinguishes between different types of movement. In the context of a christological discussion, he lists the ways in which a change can take place:

Both from Scripture and from the common notions we know about God that he is unchanging and free from alteration: he who does not undergo any quality, does not change and is not subjected to alteration. An alteration is nothing but a change with respect to quality. Not every change is an alteration, but only the change with respect to quality. There are also other kinds of change, since there are also other kinds of movement. [1] What becomes changes [...]. [2] What can increase changes [...]; this kind of movement is an addition and an increase of the quantity. [3] But when a wicked man becomes good or a good man becomes wicked, he got altered according to quality and the same happens when he recovers from illness to health, or the contrary. ${ }^{22}$

We find the same list at the beginning of the classes on Psalm 44, where Didymus explains the strange title: "For the end, concerning those who are undergoing an alteration" ( allusion to the achievement of the rational creature in the resurrection:

The alteration is a movement and a change with respect to quality. Not every movement and change are alterations. [1] It is possible to change with respect to coming to be. I say, for example,

${ }^{20}$ Cf. Didym. GenT 222, 19-25; PsT 2, 7-13; 6, 24-7, 10; EcclT 80, 1-14.

${ }^{21}$ On the use of Aristotle by Didymus: Zambon, "A servizio della verità", 129-200; Layton, Didymus the Blind and his Circle, 137-141. The name of Aristotle is mentioned in Didym. EcclT 69, 10-23; 90, 22-91, 2; 116, 14-21; PsT 77, 7-12; in other passages there are more or less explicit perifrases: EcclT 226, 23-24 ("the pagan philosopher"); 232, 21-26 ("that famous philosopher"); ZaT II 139 ("one of the ancient"); HiT 260, 18-19 ("a person ") or even more vague references. The title of an Aristotelian writing is mentioned in PsT 276, 7-10 (Cat.); EcclT 69, 10-23 (Anal.); 80, 1-14 (De int.). Literal quotations can be found in EcclT 116, 14-21 (Cat. 7 b 27-35); 232, 2126 (Cat. 3 a 29; De int. 16 b 21); 226, 23-24 (De int. 17 a 37); 236, 21-26 (De int. 16 a 9-11; 16 b 6); PsT 77, 7-12 (Top. 116 a 36-39); 276, 7-10 (Cat. 5 b 22); 303, 19-21 (De int. 16 a 9-11); 335, 16-17 (De int. 16 a 3-4); ZaT II 139 and EcclT 309, 13-18 (EN 1132 a 20-22).

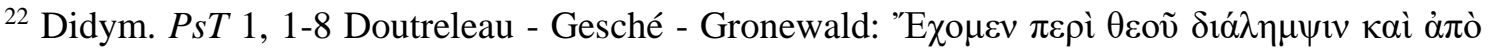

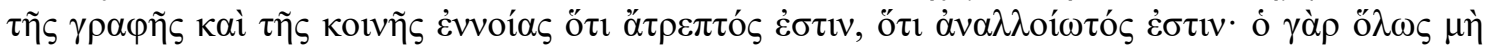
نं

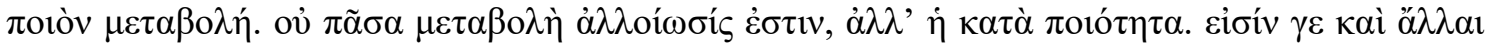

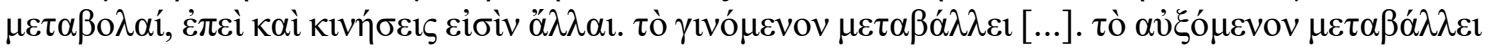

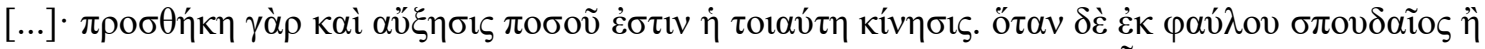

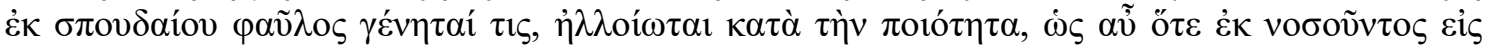

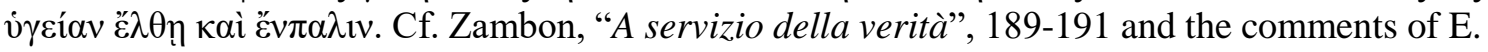
Prinzivalli in Didimo il Cieco, Lezioni sui Salmi. Il Commento ai Salmi scoperto a Tura, ed. E. Prinzivalli (Roma: Paoline, 2005) 96-98. 
that an egg becomes a bird, and that a corn seed becomes an ear. [...] [1a] There is also another change, which happens with respect to passing away: when the human body passes away and it is decomposed into fluids, worms and such things, we don't say that it has been altered, but that it has passed away. [2] There is also another movement and change with respect to increase, when an increase takes place and the quantity gets larger. [...] [3] Therefore, the alteration is a movement with respect to quality, like the passage from illness to health or from health to illness, from ignorance to science or the contrary, and from unbelief to belief. ${ }^{23}$

The same distinction appears again at the beginning of the commentary on Job: Didymus compares the physical changes, which take place through the increasing in size or the passing away of the body, to the ethical changes, which take place through a deliberation and cause the passage from virtue to vice and the contrary (HiT 1, 25-2, 5).

Didymus reproduces a classification that can be read at the beginning of Book III

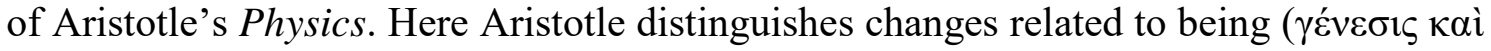

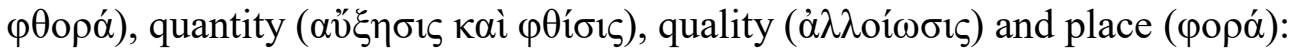

What changes, changes always with respect to substance or to quantity or to quality or to place. [...] After having distinguished in respect of each genus what is in actuality and what is potentially, the actuality of what is potentially, as such, is a motion: for example, for what is alterable, as it is alterable, actuality is alteration; for what is increasable and its opposite, decreasable (there is no common name for both), actuality is increase and decrease; for what can come to be and pass away, coming to be and passing away; of what can be carried, actuality is locomotion. ${ }^{24}$

Didymus employs the same framework, even though he does not take into account the local movement ( to the discussion of different topics (christological doctrine, the condition of human beings in the resurrection, ethics) without discussing it; Aristotle's doctrine does not interest him in itself, but insofar as it offers him a coherent reflection on the notion of

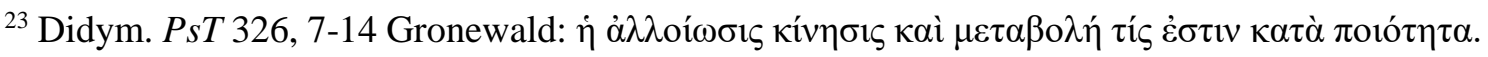

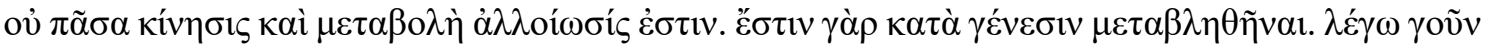

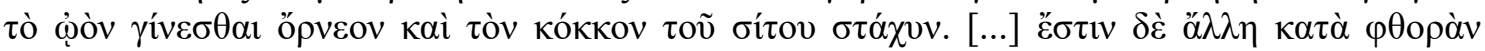

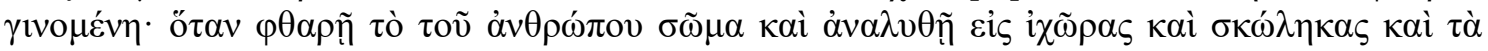

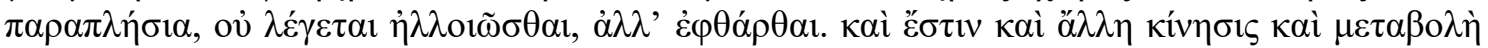

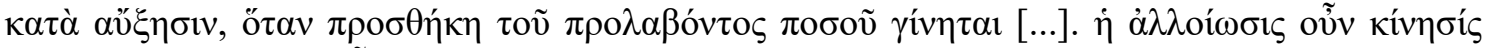

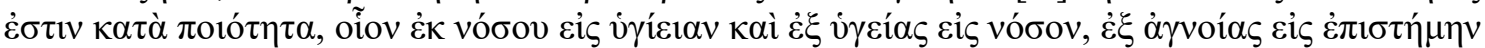

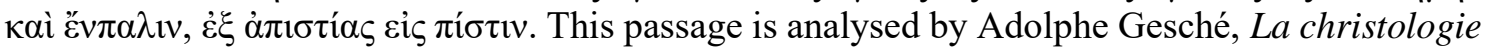
$d u$ "Commentaire sur les Psaumes" découvert à Toura (Gembloux: J. Duculot, 1962), 232-240; 262-265.

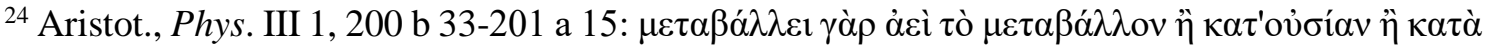

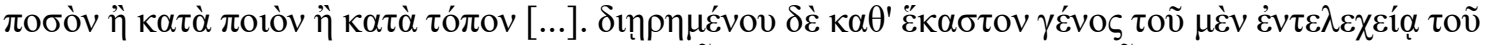

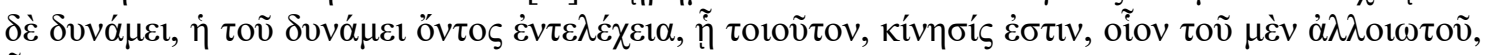

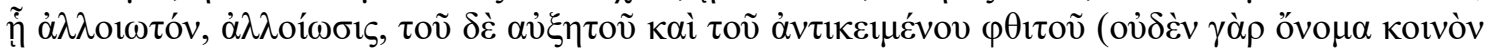

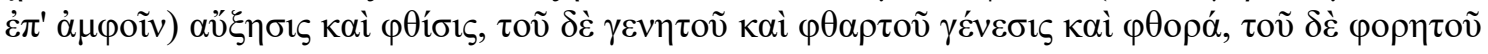
рора́.
} 
"movement", which can be applied to specific problems of Christian theology and anthropology.

Traces of Aristotle's Biology and Zoology in Didymus' Writings

Various biological and zoological explanations are scattered throughout Didymus' biblical commentaries. In several cases there are more or less significant correspondences between what Didymus writes and what we read in Aristotle's works dedicated to biology and zoology. There are, however, no real quotations, nor any explicit references to Aristotle's scientific doctrines. Didymus sometimes states that he has obtained his information from other sources, but he refers to it in a generic way, speaking of "those who have dealt with $<\ldots$. ". ${ }^{25}$ Although the possibility cannot be excluded that he - like other early or contemporary Christian authors ${ }^{26}$ - was familiar with and used some of Aristotle's biological writings, it seems more likely that the information he possessed in this area depended on intermediate sources. ${ }^{27}$

Didymus' anthropology can be defined as Aristotelian in a very generic way ${ }^{28}$ : man is a "rational mortal animal", "capable of receiving science"29; Didymus recognises the primacy and autonomy of the soul with respect to the body, but man is for him properly "the living compound, made up of soul and body" (GenT 54, 22-24). Commenting on Zec 12, 1 ("the Lord [...] moulded the spirit of man in him"), Didymus

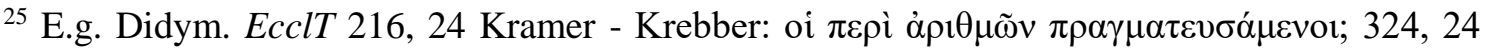

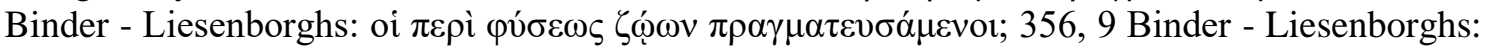

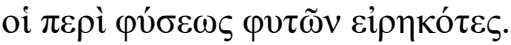

${ }^{26}$ On the use of Historia animalium by Origen, Basil and other Christian writers: Karamanolis, "Early Christian Philosophers on Aristotle", 475; Alan Scott, "Pseudo-Aristotle's Historia Animalium 9 in Origen", The Harvard Theological Review 85 (1992): 235-239.

${ }^{27}$ On the reception of the biological and zoological writings of Aristotle in the literary tradition of the mirabilia: T. Dorandi, "La ricezione del sapere zoologico di Aristotele nella tradizione paradossografica", in La zoologia di Aristotele e la sua ricezione, 59-80; G. Schepens - K. Delcroix, "Ancient Paradoxography: Origin, Evolution, Production and Reception", in La letteratura di consumo nel mondo greco-latino. Atti del Convegno internazionale. Cassino 14-17 settembre 1994, ed. O. Pecere - A. Stramaglia (Cassino: Università degli Studi di Cassino, 1996), 373-460; M.M. Sassi, "Mirabilia", in Lo spazio letterario della Grecia antica, I/2, L'ellenismo (Roma: Salerno editrice, 1993), 449-468.

${ }^{28}$ Bayliss, The Vision of Didymus the Blind, 177; Hicks, Trinity, Economy, and Scripture, 158166; Gesché, La christologie du "Commentaire sur les Psaumes", 127-131.

${ }^{29}$ Didym. PsT 143, 19; EcclT 37, 4; 213, 13-14; 234, 28; ZaT IV 3; PsT 52, 1-3 Doutreleau -

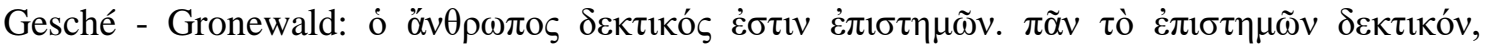

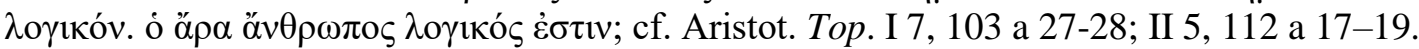


highlights the fact that - according to the prophet - God not only created the spirit of man, but created it in him, thus indicating the close union established between the human body and soul. Since Zechariah, speaking of the spirit of man, uses a verb ( $\pi \lambda \alpha \dot{\sigma} \sigma \omega)$ which the version of the LXX also uses to describe the formation of the body from the dust of the earth (Gen 2, 7), the commentator explains:

The "spirit of man" is not simply "moulded", but is "moulded in him"; in fact, it is not of corporeal nature, but of rational nature. In a proper sense, however, what is moulded is the body of man [...]. [...] about the genesis of the compound of body and soul, [Job] says: "Your hands have made me and moulded me" [Jb 10, 8]; the body has been moulded, while the soul - called spirit - has been made; and [God] has moulded it in man, making him participate, thanks to the composition, in the perceptive faculty, in such a way as to show that the whole man - endowed with soul and perceptive capacity - has become a living being. ${ }^{30}$

Didymus knew that, on the basis of some biblical passages (1 Thess 5, 23, Rom 8, 16; Dan 3, 86), some Christian exegetes - in particular his preferred author, Origen distinguished three elements in the human being: body, soul and spirit. ${ }^{31}$ In this passage however he identifies the soul with the spirit and considers man to be composed only of soul and body. ${ }^{32}$ In fact, following Philon of Alexandria and Origen, Didymus interpreted the first two chapters of Genesis to mean that the first one (Gen 1, 26-27) spoke of the rational soul, incorporeal and made in the image of God, while the second (Gen 2, 7) spoke of the moulding of the body out of the dust and of the union of the soul with it. ${ }^{33}$ He believed that because of the relationship with the body, the soul also acquired the perceptive faculties proper to the sensitive life.

Human beings therefore, in their corporeal life, like all other animals, are moved by a soul capable of perceiving. This does not detract from the fact that the human creature is superior to animals, because it is endowed with logos: Didymus speaks, in fact, of

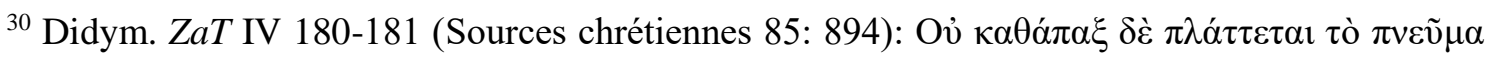

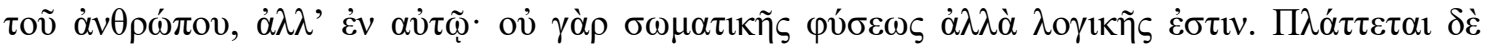

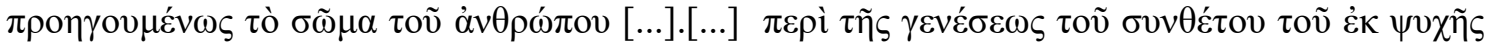

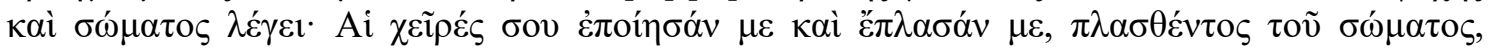

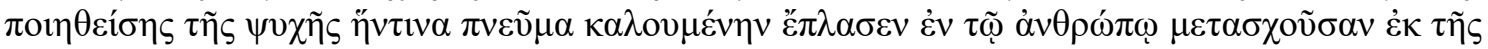

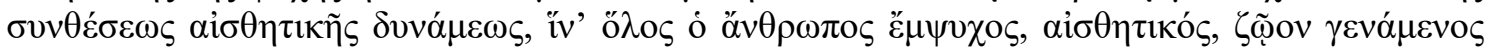
$\dot{\alpha} \pi \circ \delta \varepsilon \imath \chi \theta \tilde{\eta}$.

${ }^{31}$ Cf. Ir. Adv. haer. V 6, 1; Tat. Ad Graec. 13; Orig. Dial. 6, 20-29; Princ. II 8, 4; In Mt XIII 2; Andrè-Jean Festugière, "La trichotomie de 1 Thess. 5, 23 et la philosophie grecque", Recherches de science religieuse 20 (1930): 385-415.

${ }^{32}$ Cf. Didym. GenT 55, 11-56, 9, quoting Mt 10, 28.

${ }^{33}$ Didym. GenT 57, 22-58, 2; cf. Orig. Dial. 12, 4-14; 15, 28-16, 10; 23, 2-4; HGen I 13; HLev XIV 3; HLc VIII 2; Phil. Alex. De opif. 69.
} 
"men" as the "principal creation", to which all other animals are ordered. This superiority implies, according to him, that the human soul is immortal, while the soul of animals are mortal. ${ }^{34}$ Also according to Aristotle, man is the apex and criterion of reference for the study of all living beings because, like them, he has perceptive capacities and, in addition to them, he possesses the rational faculty. ${ }^{35}$

According to Aristotle and Didymus, human beings differ from all other animals in the fact that only humans - even though they have in common with many other animals the organs of phonation - have a voice capable of producing a word ( $\lambda$ ó $\gamma \varsigma \varsigma$ ), namely "a sound with a meaning". ${ }^{36}$ In his Politics, Aristotle specifies that the possession of the voice unites man with many animals, capable of expressing pleasure and pain. However, the possession of the ability to speak is linked to the sphere of ethical-political action and is proper to man only:

language is used to express what is useful and what is harmful, therefore also the right and the unjust; in fact, compared to other animals, it is a characteristic of humans that they alone possess the perception of the good of the bad, the right and the unjust and so on. ${ }^{37}$

The dimension of ethical action is a point on which the anthropology of Didymus is in interesting agreement with that of Aristotle. ${ }^{38}$ It is true that possessing the logos makes

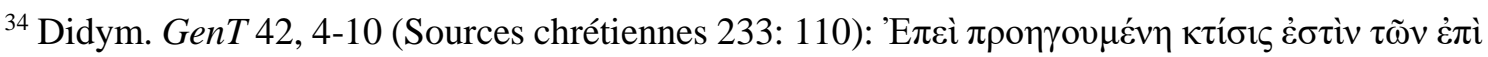

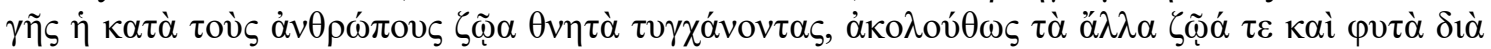

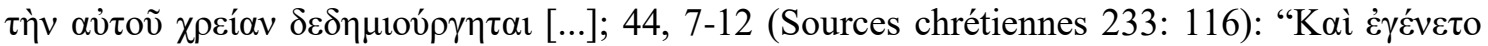

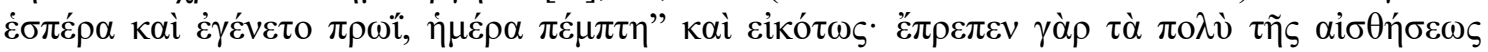

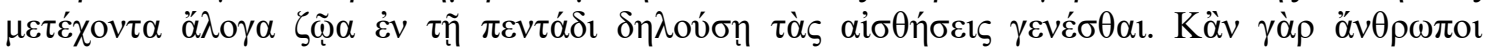

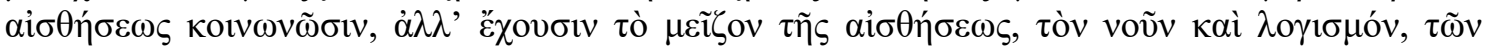

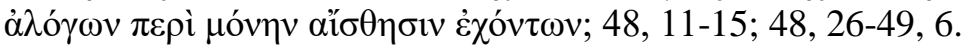

${ }^{35}$ Aristot. De an. I 1, 403 a 24-b 17; II 1, 412 a 20-21; 412 b 5-6; PA I 1, 641 a 15-23; II 10, 656 a 3-13. Cf. M.M. Sassi, "I trattati di Aristotele 'sugli animali': nascita di una disciplina", in La zoologia di Aristotele e la sua ricezione, 15-34, at 19-21; A. Falcon, "Aristotle and the Study of Animals and Plants", in The Frontiers of Ancient Science. Essays in Honor of Heinrich von Staden, ed. B. Holmes - K.-D. Fischer (Berlin - München - Boston: De Gruyter, 2015), 75-91, at 81-82; G.E.R. Lloyd, "The Relashionship of Psychology to Zoology", in Id., Aristotelian Explorations (Cambridge - New York - Melbourne: Cambridge University Press [Virtual Publishing], 2001), 38-66, at 43.
}

${ }^{36}$ Aristot. De an. II 8, 420 b 32-33; De int. 2, 16 a 29; 4, b 26; HA IV 9, 535 a 27 (cf. ps. Plat. Defin. 414 D; SVF II 167) and Didym. EcclT 95, 2-7; 98, 12-16; cf. Ronald A. Zirin, "Aristotle's Biology of Language", Transactions of the American Philological Association 110 (1980): 325347.

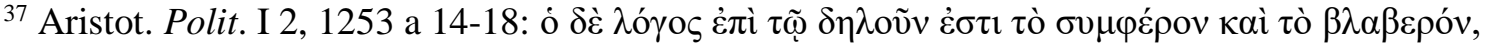

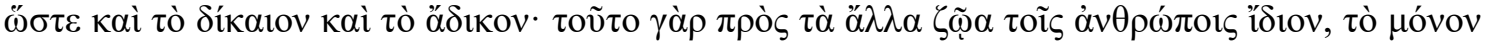

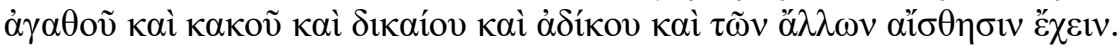

${ }^{38}$ Bayliss, The Vision of Didymus the Blind, 4-5. 
human beings different from and superior to other animals in terms of knowledge, but the latter too possess not insignificant cognitive abilities. For Aristotle the sphere in which man's most distinctive character appears is the practical sphere, because only man is the principle of his own action and is therefore capable of living according to virtues. ${ }^{39}$

Also according to Didymus, man's possession of the logos, which constitutes him "in the image and likeness" of God (Gen 1,26), is expressed specifically in the ethical dimension - that is, in the capacity, given only to human beings, to "live according to philosophy and virtue" ${ }^{\prime 0}$, because that is why they were created. Virtue and vice are, in fact, the outcome of a choice that presupposes the ability to dispose of oneself, which in turn depends on the possession of the logos; thus neither children nor irrational beings are capable of exercising virtue. ${ }^{41}$ It cannot be said that these elements prove a specific dependence on Aristotle, but they at least indicate a proximity to him in the way that Didymus reflected on certain themes.

Doctrines originating from Aristotle (or attested to in his writings) are also encountered when Didymus dwells on the description of the properties and symbolic meaning of some animals. For example, commenting on Eccl 9, 12 ("Surely the man doesn't know his time: as fishes which are taken in an evil net [...]”), he reports an opinion, attributed to "learned men", according to which there are fishes which possess a kind of language. There is a passage in the Deipnosophistae of Athenaeus, where Aristotle is mentioned as holding this opinion:

It has been well said by some learned men - I don't know if it is also true, anyway it has been well said - that if a parrotfish, after having been caught in a net, manages to escape from it, it is impossible for that day to find another fish of the same kind in the same place. [...] With some special sign of theirs, they give directions to those which were absent. ${ }^{42}$

\footnotetext{
${ }^{39}$ Aristot. EE II 5, 1222 b 19-20; cf. Sassi, "I trattati di Aristotele 'sugli animali", 16-17.

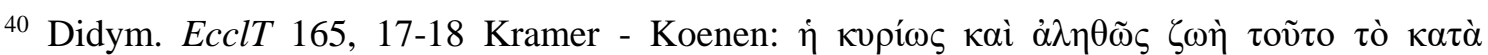

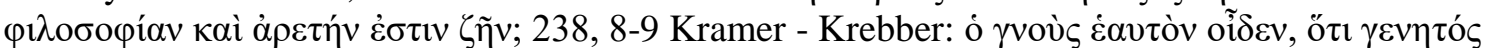

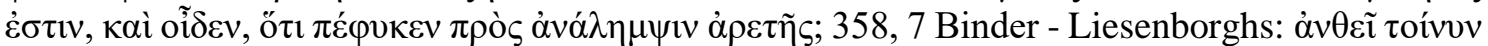

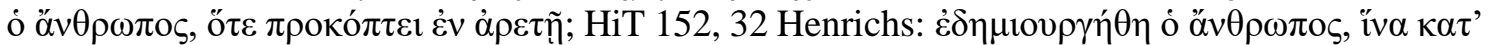

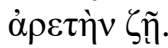

${ }^{41}$ Didym. PsT 30, 13-18; 93, 21-26; EcclT 338, 25-339, 4; GenT 1, 25-2, 5; HiT 5, 1-7; ZaT II 347.

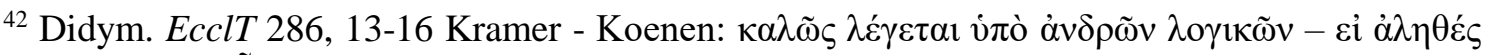

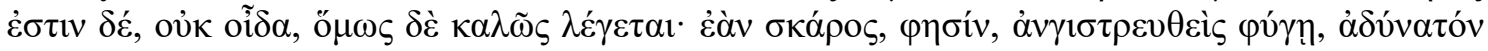

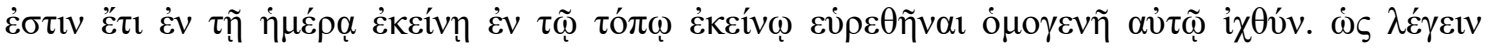

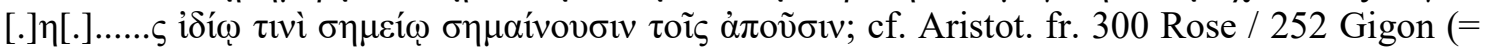

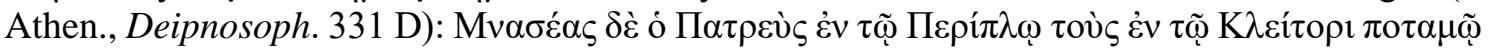


The complaint of the Psalmist in Psalm 21, 7 "I am a worm and not a man" is explained by Didymus as a reference either to the humiliation of the Christ or to his birth from a virgin:

Since [the Christ] did not receive his body from the sowing of human seeds, but only from the matter taken from the woman who gave him birth, therefore [the Psalmist] calls him a worm; the worm is not engendered from the copulation, but from the simple matter. ${ }^{43}$

Spontaneous generation is dealt with by Aristotle in De generatione animalium and in Historia animalium $\mathrm{V}$ and VI. ${ }^{44}$ In Historia animalium V 19, examining the ways in which insects are generated, Aristotle talks about some kinds of insects arising out of

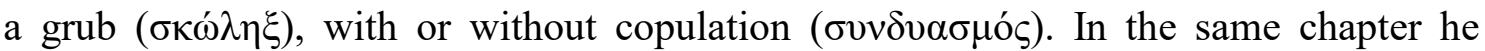
mentions various types of insects and intestinal worms ( $\check{\varepsilon} \lambda \mu v v \theta \varepsilon \varsigma)$ arising spontaneously ( $\left.\alpha \jmath \tau^{\prime} \mu \alpha \tau \alpha\right)$ from different materials (dew, mud, manure, wood, hairs, flesh, excrement). ${ }^{45}$ Of the complex cases and distinctions made by Aristotle there is nothing in the brief mention made by Didymus, except the coincidence in the use of the terms $\sigma \kappa \omega \dot{\omega} \lambda \eta \xi$ (also found in the text of the LXX) and $\sigma v v \delta v \alpha \sigma \mu$ ó $\zeta$, which Aristotle was the first to use. It is very probable, therefore, that the interpretation of the worm as the image of the virginal birth of Jesus - although originating in the Aristotelian doctrine of the spontaneous generation of certain types of $\sigma \kappa \omega \dot{\lambda} \eta \xi$ - was elaborated by a previous author, perhaps Origen $^{46}$, and taken up by Didymus.

Explaining Psalm 41, Didymus mentions the symbolical meaning of the deer and quotes a proverb concerning it:

When [the deer] gets old and sheds its horns, it conceals itself somewhere, until new horns grow and get strong; as long as it doesn't have its horns it is easier to capture it: in fact, they are its

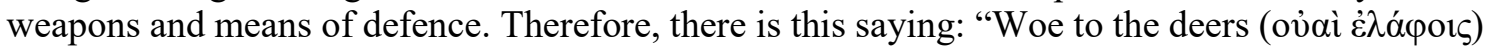

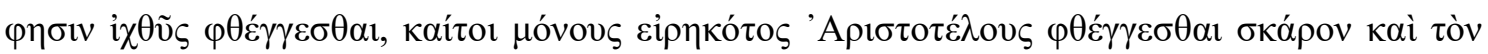

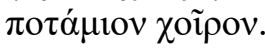

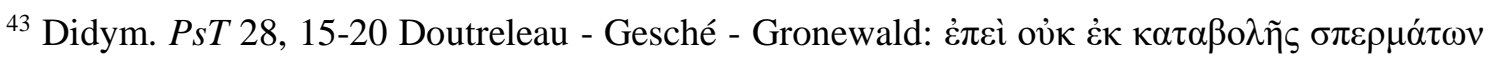

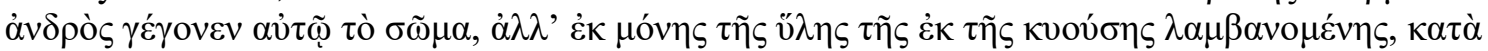

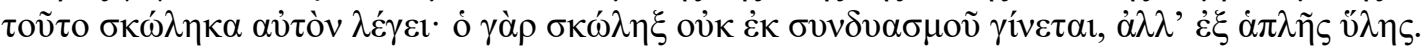

${ }^{44}$ On this topic: G.E.R. Lloyd, "Spontaneous Generation and Metamorphosis", in Id., Aristotelian Explorations, 104-125; David M. Balme, "Development of Biology in Aristotle and Theophrastus: Theory of Spontaneous Generation", Phronesis 7 (1962): 91-104.

${ }^{45}$ Aristot. $H A$ V 19, 551 a 6-13. 27-29.

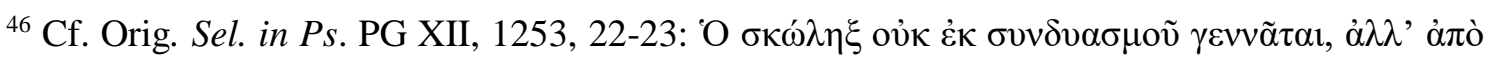
$\xi v 0 \lambda o v$; the scholia published in the Patrologia Graeca under the name of Origen are, however, of uncertain attribution. 
which do not have their horns!". This proverb implicitly signifies: "Woe to the man, who has no help". ${ }^{47}$

A similar passage concerning the deer in the Historia animalium of Aristotle gives a different spelling and interpretation of this proverb:

They shed their horns in places difficult of access and discovery, whence the proverbial expression of "the place where the deers (oṽ $\alpha i$ غ̇ं $\lambda \alpha \varphi \circ$ ) shed their horns"; the fact being that, as having parted with their weapons, they take care not to be seen. ${ }^{48}$

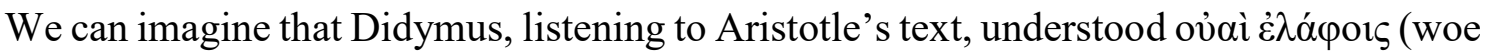
to the deers) instead of oũ $\alpha i$ č $\lambda \alpha \varphi \varphi$ (where the deers), or that he was misled by his memory. But it is easier to think that there has been an intermediate source between him and Aristotle.

Another animal whose characteristics Didymus describes in a way reminiscent of Aristotle is the hoopoe. Commenting on Zec 5, 9 LXX ("[...] behold, two women coming out. [...] and they had wings like the wings of a hoopoe"), Didymus explains the strange comparison in this way:

To show the fact that the wings of those women are worthy of blame, they have been compared and declared similar to the hoopoe's wings. This animal is impure, as it loves corpses and human excrements; it feeds at the graves and builds its nest with human excrement, laying its eggs in this unhealthy shelter, so that it can hatch and give birth to little ones similar to itself. ${ }^{49}$

A passage in Book IX of the Historia animalium contains the information that "the hoopoe usually constructs its nest out of human excrements" $"$, but in the quoted passage Didymus offers other information about this bird (the hoopoe was used to

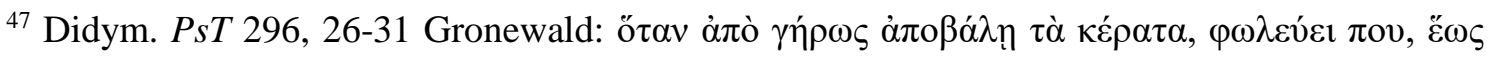

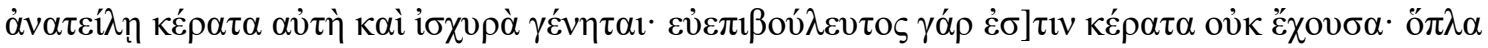

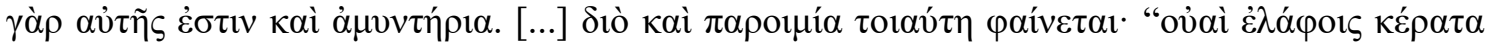

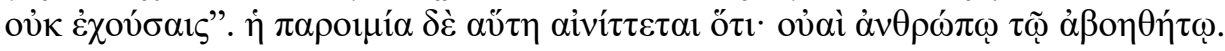

${ }^{48}$ Aristot. HA IX 5, 611 a 25-27.

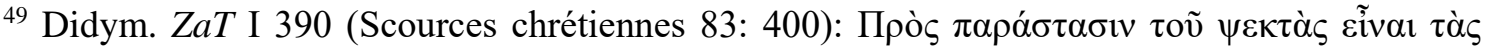

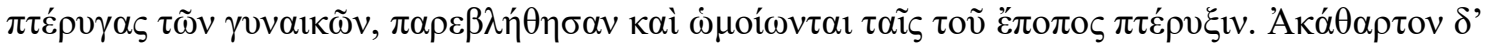

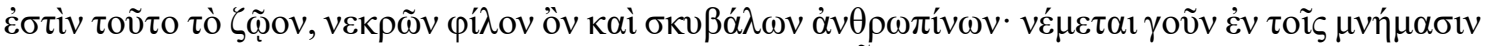

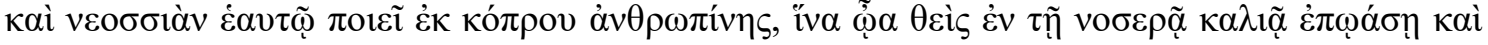

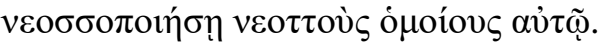

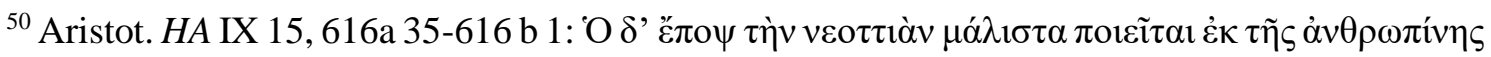

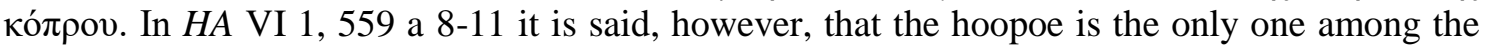
birds that does not build a nest.
} 
provoke abortions and to make love filters), which is not found in Aristotle and which supposes a different source. ${ }^{51}$

I quote a last example of how Didymus used biological knowledge that can refer, at least indirectly, to Aristotle. In the commentary on the book of Job (10, 10: "Didn't you press me out like milk and didn't you curdle me like cheese?") we find a short report on embryology:

[Job] calls "pressed out milk" the seed out of which the animal is made; and as the curdled milk becomes cheese, so the seed, after having been curdled, becomes nature. This condition comes before the embryo. The seed sown in the furrows of the womb, when it has been curdled like cheese, becomes nature, which in turn receives a shape or, as the Scripture says, the "image" [of God] and is impressed with something like distinctive marks. But when the limbs have been distinguished and each of them is separated from the other and acts like the hand or the foot of an animal, at that time the birth of the embryo shows openly the animal. ${ }^{52}$

The formation of the embryo is also described in the comment on Eccl 11, 5 ("as you do not know the bones in the womb of a pregnant woman, so you will not know the works of God"). There Didymus refers explicitly to the theories of "those who have dealt with the nature of animals" to expose the process of formation of the fetus' organs: digested food is transformed into blood, while what has not been digested is expelled. The blood condenses into flesh, while what remains of it forms hair, hairs and nails. Didymus points out that biologists do not know how to describe the origin of bones, confirming what Scripture says: "my bone was not hidden from you, which you did in hiding" (Ps 138, 15). As for the formation of the embryo, it comes from the condensed sperm. As it condenses, it is transformed into "nature" ( $(v \dot{\sigma} \sigma 1 \varsigma)$, which in turn is transformed into flesh, and the embryo, which has become a living being, can be given birth. ${ }^{53}$ This process is

${ }^{51}$ ZaT I 391; L. Doutreleau, “Introduction”, in Didyme l'Aveugle, Sur Zacharie, 3 vols., ed. L. Doutreleau (Paris: Les éditions du Cerf, 1962), 1: 115-116.

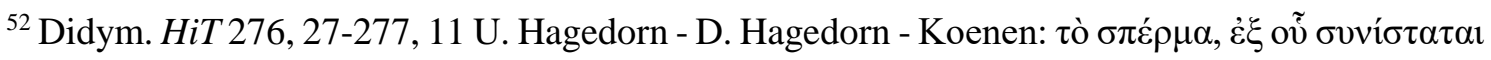

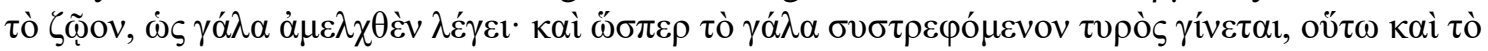

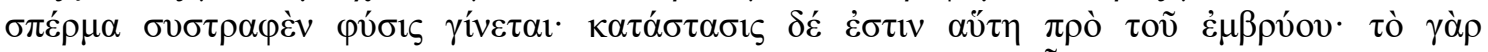

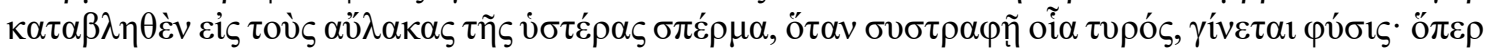

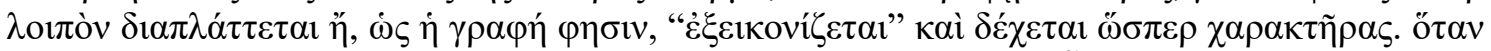

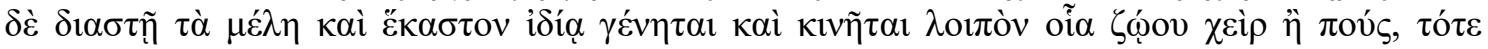

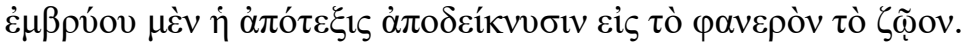

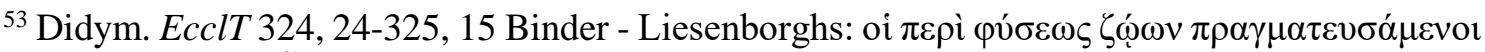

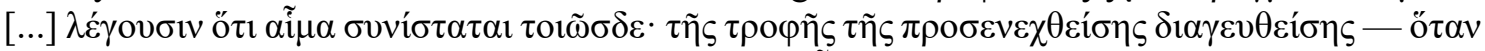

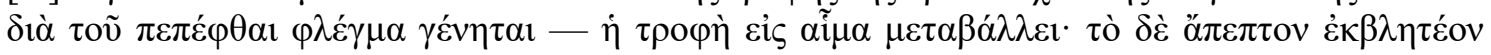

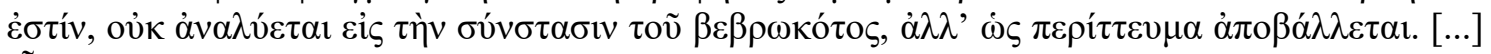

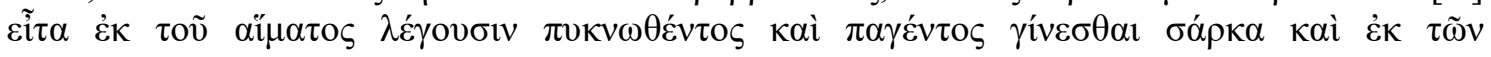

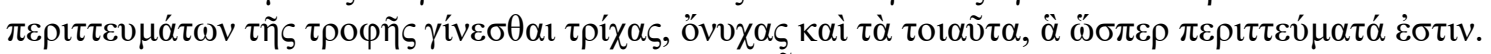

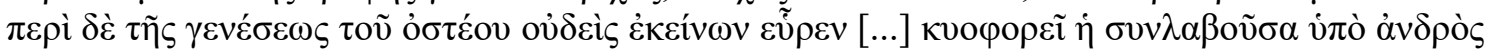


mentioned, in shorter terms, in the commentary on the title of Psalm 44 ("For the end, for those who are undergoing an alteration"), to which we have already referred. Here Didymus compares the change that is produced in the passage from the seed to the embryo to the change that is produced in the resurrected body compared to the mortal body. ${ }^{54}$

In De generatione animalium Aristotle offers a description of the genesis of the embryo similar in some passages to the one we read in Didymus:

When the female's secretion in the uterus has been fixed by the semen of the male, which acts in a similar way to rennet - and in fact rennet is milk that contains vital heat $[\ldots]-,[\ldots]$ membranes are formed. When the embryo has been formed, it acts similarly to the seeds that are sown. The first principle [of growth], in fact, is also contained in the seeds. And when this principle has been differentiated - while before it was contained potentially - the bud and root are pushed out of it; the root is the one through which [the plant] receives nourishment. [...] in fact what exists grows and the final nourishment of an animal is blood or something similar. ${ }^{55}$

The image of the curdled milk which becomes cheese is used both by Aristotle and Didymus to describe the development of the embryo. ${ }^{56}$ But for Aristotle the seed is like rennet - it is the agent of the curdling process - whereas for Didymus it is the object of that process. Like Aristotle, Didymus believes that the blood is the final stage of transformation of nourishment ${ }^{57}$, but there are also other elements (for instance the Stoic doctrine that the first stage of development of the embryo is the $\varphi v ́ \sigma ı \varsigma^{58}$ ) and the whole

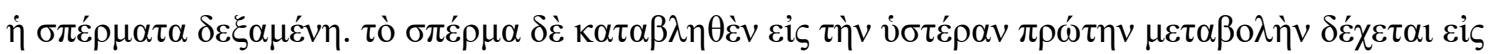

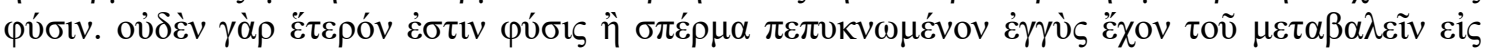

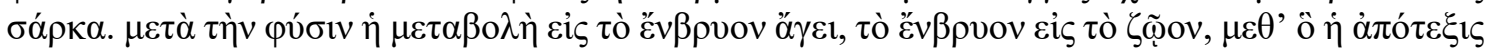

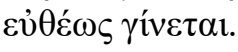

${ }^{54}$ Didym. PsT 329, 25-28; cf. EcclT 103, 4-12.

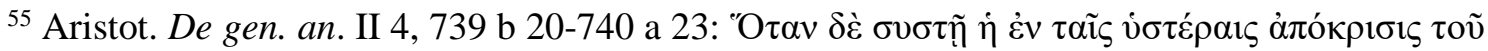

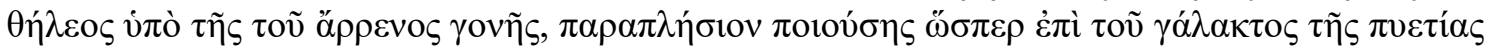

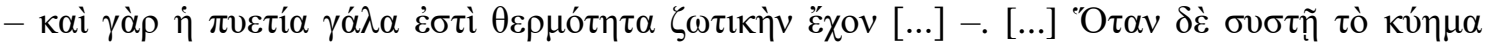

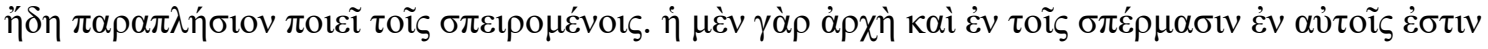

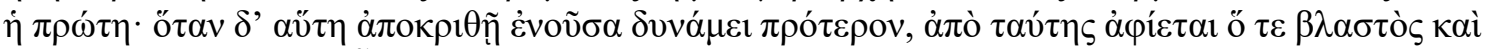

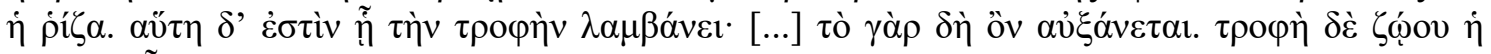

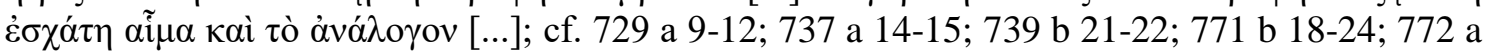
$22-23$.

${ }^{56}$ On ancient embryology: A. Gotthelf, "Teleology and Embryogenesis in Aristotle's Generation of Animals 2.6", in The Frontiers of Ancient Science. Essays in Honor of Heinrich von Staden, ed. B. Holmes - K.-D. Fischer (Berlin - München - Boston: de Gruyter, 2015), 139-174; L'embryon: formation et animation. Antiquité grecque et latine, tradition hébraïque, chrétienne et islamique, ed. L. Brisson - M.-H. Congourdeau - J.-L. Solère (Paris: Vrin, 2008); L'embryon humain à travers l'histoire. Images, savoirs et rites, ed. V. Dasen (Gollion CH: Infolio, 2007).

${ }^{57}$ On the function of blood for Aristotle: G.E.R. Lloyd, "The Relashionship of Psychology to Zoology", 44.

${ }^{58}$ Cf. SVF II 743.745. 
picture Didymus gives doesn't show any direct dependence from the Aristotelian writings.

The conclusion of this brief review is rather poor: Didymus possessed a considerable amount of knowledge of philosophical and scientific culture, but was not a philosopher in the way his pagan contemporaries were. Philosophical and scientific doctrines were not studied by him for themselves, but only in order to use them to explain biblical passages, as a complement to their interpretation or as tools to discuss the problems arising from theological teachings.

Several passages in the works of Didymus show an explicit reference to Aristotle or to one of his writings. Almost all these passages are not in the published commentaries, but in the transcript of the classes given by Didymus on Psalms and Ecclesiastes. It seems, therefore, that philosophical topics were openly discussed in the circle of the school, but not in the works composed for a larger written circulation. It is also clear that the pupils of Didymus were acquainted with Aristotle: the teacher quotes passages and uses Aristotelian doctrines, though he never explains them directly.

From the explicit quotations and more extensive discussions of some themes it appears that Didymus certainly knew the logical corpus of Aristotle and perhaps also other works by him. It is not possible to say whether Didymus derived his direct knowledge of Aristotle from his scholastic training in grammar and rhetoric (which limited his interest to certain logical writings) and had only an indirect, albeit good, knowledge of other Aristotelian doctrines, or whether he had a greater knowledge of the Aristotelian corpus than appears in his writings.

In any case, we do not find in his writings any direct quotation or explicit reference to Aristotle's biological works. It can be said that some aspects of Didymus' anthropology and ethics have a more explicit Aristotelian colour than his contemporaries. Moreover, in several cases the naturalistic observations he makes in his biblical commentaries correspond to the writings of Aristotle. But Didymus dedicated to the study of nature the encyclopaedic curiosity of an amateur, not a speculative and systematic interest, and his knowledge in this field probably depended on sources - such as the collections of mirabilia - whose origin it is not possible to determine more precisely, because he never mentions either authors or titles, but among them it is not probable that there were the biological writings of Aristotle. 
Marco Zambon

University of Padova

References

Bayliss, Grant. (2015) The Vision of Didymus the Blind. A Fourth-Century Virtue-Origenism. Oxford: Oxford University Press.

Beatrice, P.F. (2006) "The Treasures of the Egyptians. A Chapter in the History of Patristic Exegesis and Late Antique Culture", in Studia Patristica, XXXIX, ed. M.J. Edwards - P. Parvis - F. Young, Leuven: Peeters: 159-183.

Brisson, L.; Congourdeau, M.-H. and Solère, J.L. (2008) L'embryon: formation et animation. Antiquité grecque et latine, tradition hébraïque, chrétienne et islamique, Paris: Vrin.

Crouzel, Henry. (1962) Origène et la philosophie. Paris: Aubier: 31-35.

Dasen, V. (2007) L'embryon humain à travers l'histoire. Images, savoirs et rites, Gollion CH: Infolio.

Diekamp, Franz. (1899) Die origenistischen Streitigkeiten im 6. Jahrhundert und das fünfte allgemeine Concil. Münster: Aschendorff: 129-138.

Dillon, J. (2016) "The Reception of Aristotle in Antiochus and Cicero", in Brill's Companion to the Reception of Aristotle in Antiquity: 183-201.

Dodds, E.R. (1954) Proclus, The Elements of Theology, Oxford: At the Clarendon Press.

Doutreleau, L. (1959) "Vie et survie de Didyme l'Aveugle du IVe siècle à nos jours", in Les mardis de Dar-el-Salam 1956-1957, Paris: Vrin, 1959: 33-92.

Doutreleau, Louis. (1955) “Que savons-nous aujourd'hui des papyrus de Toura?”, Recherches de science religieuse 43: 161-176.

Edwards, Mark. (2019) Aristotle and Early Christian Thought. London - New York: Routledge.

Elders, L.J. (1994) "The Greek Christian Authors and Aristotle", in Aristotle in Late Antiquity, ed. L.P. Schrenk. Washington D.C.: The Catholic University of America Press: 111-142.

Falcon, A. (2015) "Aristotle and the Study of Animals and Plants", in The Frontiers of Ancient Science. Essays in Honor of Heinrich von Staden, ed. B. Holmes - K.-D. Fischer (Berlin München - Boston: De Gruyter, 75-91.

Feola, G. (2017) “Alcune considerazioni sull'ordinamento del corpus biologico di Aristotele”, in La zoologia di Aristotele e la sua ricezione dall'età ellenestica e romana alle culture medievali. Atti della X settimana di Formazione del centro GrAL, Pisa, 18-20 novembre 2015, ed. M.M. Sassi - E. Coda - G. Feola. Pisa: Pisa University Press: 35-57.

Festugière, A.J. (1932) "Excursus C: Aristote dans la littérature grecque chrétienne jusqu'à Théodoret", in Id., L'idéal religieux des Grecs et l'Évangile. Paris: Gabalda, 221-263.

Frede, M. (2005) "Les Catégories d'Aristote et les Pères de l'Église grecs", in Les Catégories et leur histoire, ed. O. Bruun - L. Corti. Paris: J. Vrin: 135-173.

Ghellinck, Joseph. (1930) "Quelques appréciations de la dialectique et d'Aristote durant les conflits trinitaires du IVe siècle”, Revue d'histoire ecclésiastique 26: 5-42. 
Gotthelf, A. (2015) "Teleology and Embryogenesis in Aristotle's Generation of Animals 2.6", in The Frontiers of Ancient Science. Essays in Honor of Heinrich von Staden, ed. B. Holmes - K.D. Fischer. Berlin - München - Boston: de Gruyter, 139-174.

Guillaumont, Antoine. (1962) Les "Kephalaia gnostica” d'Èvagre le Pontique et l'histoire de l'Origénisme chez les Grecs et les Syriens. Paris: Seuil: 81-136.

Hatzimichali, M. (2016) "Andronicus of Rhodes and the Construction of the Aristotelian Corpus", in Brill's Companion to the Reception of Aristotle in Antiquity: 81-100.

Hicks, Jonathan. (2015) Trinity, Economy, and Scripture: Recovering Didymus the Blind. Winona Lake: Eisenbrauns.

Karamanolis, G. (2016) "Early Christian Philosophers on Aristotle", in Brill's Companion to the Reception of Aristotle in Antiquity, ed. A. Falcon. Leiden - Boston: Brill, 460-479.

Koenen, Ludwig and Doutreleau, Louis. (1967) "Nouvel inventaire des Papyrus de Toura", Recherches de science religieuse 55: 547-564.

Koenen, Ludwig and Müller-Wiener, Wolfgang (1968) "Zu den Papyri aus dem Arsenioskloster bei Tura", Zeitschrift für Papyrologie und Epigraphik 2: 41-63.

Layton, Richard. (2004) Didymus the Blind and his Circle in Late Antique Alexandria. Virtue and Narrative in Biblical Scholarship. Urbana - Chicago: University of Illinois Press.

Lilla, S. (1983) "Aristotelismo", in Dizionario patristico di antichità cristiane, ed. A. Di Berardino (Casale Monferrato: Marietti 1: 349-363.

Lloyd, G.E.R. (2001) "The Relashionship of Psychology to Zoology", in Id., Aristotelian Explorations (Cambridge - New York - Melbourne: Cambridge University Press [Virtual Publishing], 38-66.

Moraux, Paul. (1951) Les listes anciennes des ouvrages d'Aristote. Leuven: Éditions Universitaires de Louvain.

Moraux, Paul. (1973) Der Aristotelismus bei den Griechen Von Andronikos bis Alexander von Aphrodisias, I. Berlin - New York: Walter de Gruyter: 3-93.

Pereira, M. (2011) "From the Spoils of Egypt: An Analysis of Origen's Letter to Gregory", in Origeniana Decima. Origen as Writer. Papers of the 10th International Origen Congress, ed. S. Kaczmarek - H. Pietras - A. Dziadowiec, Leuven - Paris - Walpole MA: Uitgeverij Peeters: 221248.

Plaxco, K. (2013) "Didymus the Blind and the Metaphysics of Participation", in Studia Patristica, LXVII, ed. M. Vinzent. Leuven: Peeters, 227-237.

Ramelli, Ilaria. (2013) “Alexander of Aphrodisias: A Source of Origen's Philosophy?", Philosophie Antique 13: 1-49.

Runia, David (1989) "Festugière Revisited: Aristotle in the Greek Patres", Vigiliae Christianae 43: 1-34.

Sassi, M.M. (2017) "I trattati di Aristotele 'sugli animali': nascita di una disciplina", in $L a$ zoologia di Aristotele e la sua ricezione dall'età ellenestica e romana alle culture medievali. Atti della X settimana di Formazione del centro GrAL, Pisa, 18-20 novembre 2015: 15-34.

Zachhuber, Johannes (2005) "Das Universalienproblem in der griechischen Patristik und im frühen Mittelalter”, Millennium 2: 137-174.

Zambon, M. (2018) "Didyme l'Aveugle", in Dictionnaire des philosophes antiques, ed. R. Goulet. Paris: CNRS Éditions 7: 485-513. 
Journal of Ancient Philosophy, vol. 15 issue 2, 2021.

DOI: http://dx.doi.org/10.11606/issn.1981-9471.v15i2p190-209 